\title{
Innovation and Firm Growth: Is R\&D worth it?
}

\section{PELIN DEMIREL}

Nottingham University Business School, Wollaton Road, Nottingham NG8 1BB, UK.

Email: pelin.demirel@nottingham.ac.uk

\section{MARIANA MAZZUCATO}

The Open University, Economics Department, Walton Hall, Milton Keynes, MK7 6AA, UK.

Email: m.mazzucato@open.ac.uk

Draft: March 18, 2010

\begin{abstract}
The paper contributes to an emerging literature that critically questions the degree to which $\mathrm{R} \& \mathrm{D}$, at the centre of national innovation policies, results in firm growth. The differences in how innovation affects firm growth is explored for small and large publicly quoted US pharmaceutical firms between 1950 and 2008. We observe that the positive impact of R\&D on firm growth is highly conditional upon a combination of firm characteristics such as firm size, patenting and persistence in patenting. For large pharma firms, R\&D affects firm growth positively with the exception of those that do not patent. On the other hand, for small firms, R\&D boosts growth for only a small subset of firms: namely those that patent persistently for a minimum of 5 years. The results also provide some important insights for our understanding of the structural characteristics underlying 'fat tails' in firm growth distributions: the tails are fattest when the sample in question includes the persistent innovators.
\end{abstract}

Key words: innovation, persistence, firm growth, pharmaceutical industry.

JEL Classifications: L1 Market Structure, Firm Strategy, and Market Performance, 03 Technological Change.

\section{Acknowledgements:}

The research leading to these results has received funding from the European Community's Seventh Framework Programme (FP7/2007-2013) under Socio-economic Sciences and Humanities, grant agreement $\mathrm{n}^{\circ} 217466$ (www.finnov-fp7.eu). Both authors are grateful to the ESRC Innogen centre for support. 


\section{Introduction}

The economics of innovation literature often assumes a direct causal link between innovation and economic growth. This belief has directly translated into policies aimed at achieving innovation led growth: innovation is seen as one of the most important means through which firms compete, and grow, especially in the current era of the knowledge economy (Mason et al., 2009). Policy makers thus inherently attach great importance to innovation activities such as business $R \& D$ and patenting (see for example DIUS Annual Innovation Report, 2008).

Yet, surprisingly, there are actually very few studies which prove that innovation done by large or small firms actually increases their growth performance. Some studies have found a positive impact of innovation on growth (Geroski and Machin, 1992; Geroski and Toker 1996; Yasuda. 2005) while others no significant impact (Almus and Nerlinger ,1999; Bottazzi et al., 2001; Lööf and Heshmati, 2006), and still others even a negative impact (Brouwer et al., 1993; Freel and Robson, 2004). The inconclusiveness of these studies motivates the paper's provocative question: given the huge costs of $R \& D$, is it worth it?

This inconclusiveness also raises a more general question related to market selection: Do markets 'choose' the 'best' firms? In fact, both the Schumpetarian and more mainstream industrial economics literature assume that it is the more innovative and efficient firms that will grow more, causing the question about whether market selection rewards innovative firms to be side stepped. But the studies above suggest that perhaps markets do not choose the most innovative firms. Or perhaps they choose only those with a particular mix of innovation characteristics.

These questions are of utmost relevance to innovation and competition policy. The European Commission's (EC) Lisbon Agenda, advocates that firms should spend more on R\&D, with a target of $3 \%$ of GDP in aggregate figures. But if $\mathrm{R} \& \mathrm{D}$ does not necessarily boost firm growth as suggested by the mixed empirical evidence, and if innovative firms do not outperform noninnovative firms, it is potentially dangerous to ask firms to spend more on R\&D.

The paper is motivated by these findings. We ask whether market selection fails to reward innovators or whether it rewards only certain types of innovative firms. We focus on pharmaceutical firms (from now on 'pharma') quoted on the US stock market from 1950 to 2008. The pharma industry is a particularly interesting industry to study in this context since although both $R \& D$ spending and patents have risen exponentially since the $1980 \mathrm{~s}^{1}$, the number of new

\footnotetext{
${ }^{1}$ This is due both to (1) institutional factors like the 1980 Bayh-Dole Act which allowed publicly funded research to be patented (Mowery and Ziedonis, 2002) - and to (2) competitive factors, such as the need for firms in this industry to constantly produce blockbuster drugs and/or to extend the patent life of existing drugs.
} 
drugs (New Molecular Entities) has remained relatively flat—leading to a sort of 'R\&D paradox'2 illustrated in Figure 1.

\section{Figure 1: R\&D and New Drug Discoveries in Pharma}

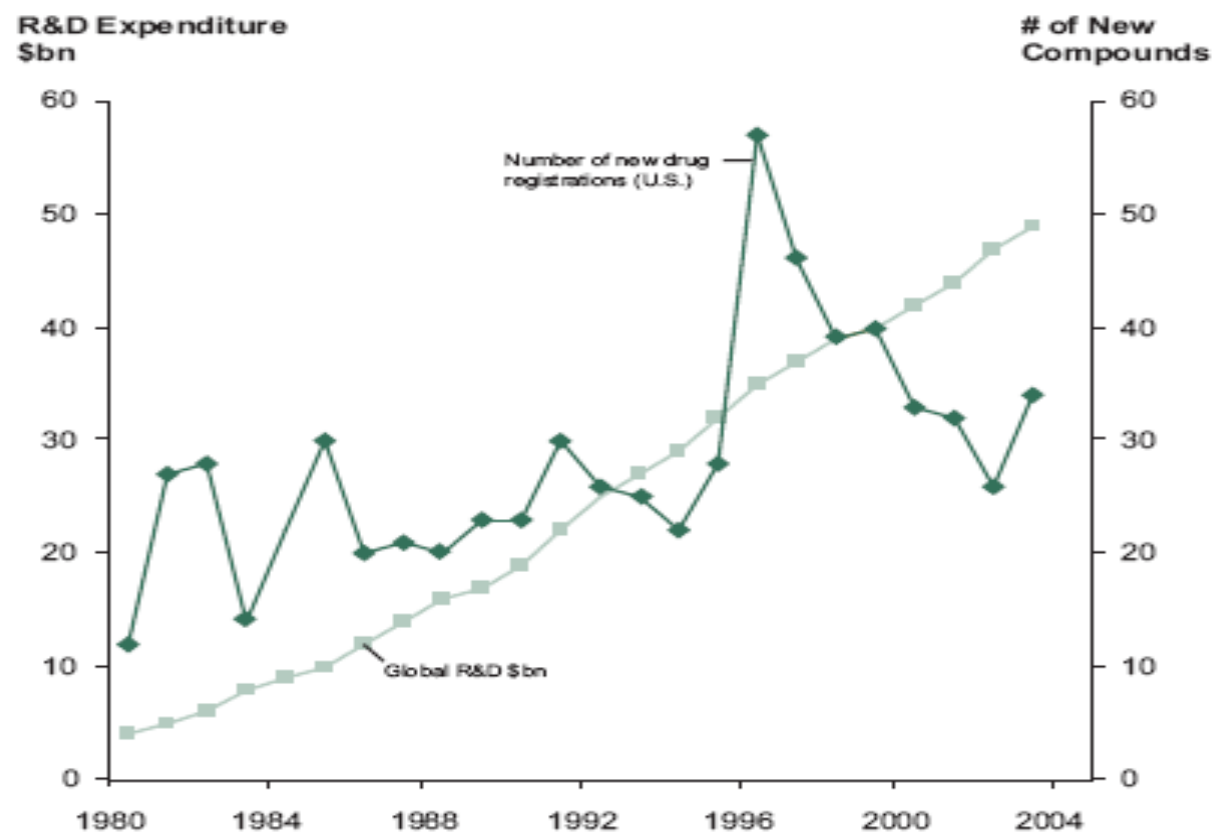

Source: McKinnon et al. (2004)

We focus on how different firm specific characteristics impact on the effect of $R \& D$ on firm growth. These characteristics are firm size, firm patenting, and the capability to patent 'persistently'. Furthermore, as the characteristics of the innovation process have undergone fundamental change since the 1980s's, from a period of random screening to guided search (Gambardella, 1995), largely attributed to advances in genomics and IT, this allows us to test whether this change in 'innovation regime' has affected the R\&D-growth relationship. The fact that the latter period was also characterized by a new division of innovative labor between large and small firms - with large pharma focusing more on the marketing and distribution efforts around new drugs, while small dedicated firms, often biotech related, focus on the more uncertain process of innovation around niche drugs - makes the investigation of the growth dynamics of large vs. small pharma particularly interesting.

Our results highlight the key role that persistence in firm patenting plays in allowing small firms to benefit from their R\&D efforts: $R \& D$ affects growth only for those small firms that have patented

\footnotetext{
${ }^{2}$ Provocatively we call this an 'innovation paradox' recalling the debates in the late 1990s on the 'productivity paradox' or the 'computer paradox' which asked why spending on IT technology did not appear to result in higher productivity or growth in the economy ("We see computers everywhere except in the productivity statistics." (Solow, 1987)).
} 
5 years in row. No growth benefit for small firms that patent sporadically. Interestingly, persistence is less important for large firms than for small firms. We discuss the implications of this result in the conclusion.

Finally, the results provide initial insights into the source of the complex behavior in firm growth rate distributions, which have received recent attention in the firm growth literature (Cabral and Mata, 2003; Bottazzi and Secchi, 2005), as well as in the finance literature. In particular, we find that 'fat tailed' distributions are more likely to be present amongst firms that have the characteristics which we find are needed for $R \& D$ to translate into growth.

The paper is organized as follows. Section 2 briefly reviews the literature that considers the impact of innovation on firm growth and discusses the empirical focus of the paper. Section 3 reviews the data and methodology used in the study. Section 4 discusses the results. Section 5 highlights the implications for understanding fat tails in firm growth rate distributions. Section 6 concludes.

\section{Innovation and firm growth}

The patterns and sources of firm growth continue to puzzle economists and management scholars due to the amount of mixed evidence on the structure of growth and the variety of sources that drive growth (Westhead and Birley, 1995). This literature often goes back to the influential work of Gibrat (1931), who found that firm growth often looks like a random walk. Studies have found that growth is more 'structured' when there are drivers leading to dynamic increasing returns. Among such drivers is innovation, especially in the more mature phase of the industry life-cycle characterized by more scale economies and more cost cutting 'process' innovations (Klepper, 1996).

The empirical work on firm growth that our paper builds on most closely, is an emerging literature which acknowledges that the impact of innovation on growth is indeed different for different types of firms such as slow and fast growing firms (Coad and Rao, 2008; Mason et al., 2009); firms with different levels of R\&D intensity (Del Monte and Papagni, 2003); low-tech and high-tech firms (Stam and Wennberg, 2009) and firms with a focus on product or process innovations (Brouwer et al., 1993). Given the heterogeneity in firms' innovative activities within an industry and within size classes, it is important to understand whether and how firm-level differences shape the impact of innovation on firm growth.

Inspired by this literature, to study the impact of innovation on firm growth, we focus on: (1) the innovative differences between size classes and (2) the innovative differences within size classes. 


\section{(1) Innovative differences between size classes}

Firstly, the innovative characteristics of firms differ by size. In general, small and large firms conduct different types of innovative activities that vary in scale, scope, and efficiency. This is especially true in the pharmaceutical industry where a new 'division of innovative labor' emerged, since the 1980's where small biotech companies and small pharma firms focus on niche areas of new molecular entity discovery (often initiated by major investments of state funded laboratories) while large pharma firms focus on the development side of the R\&D equation as well as the marketing of the drugs.

Small firms tend to explore more the novel technologies and concentrate on product innovations while large firms, in many different industries especially during the 'mature' phase of the industry life-cycle, excel in process innovations and incremental changes to established technologies (Klepper, 1996). Small firms also differ from large firms by conducting innovations on a less persistent basis (Cefis, 2003; Geroski et al., 1997) and undertaking more informal R\&D that is distributed among various operational units (Santarelli and Sterlacchini, 1990).

As can be seen in Figure 2 below, the number of small pharma firms has increased substantially over the years. Moreover, as can be seen in Figure 3, the share of small patentee firms increased over time, highlighting the growing innovative role of small pharma firms.

Figure 2: Number of Firms in Pharma Classified According to Firm Size

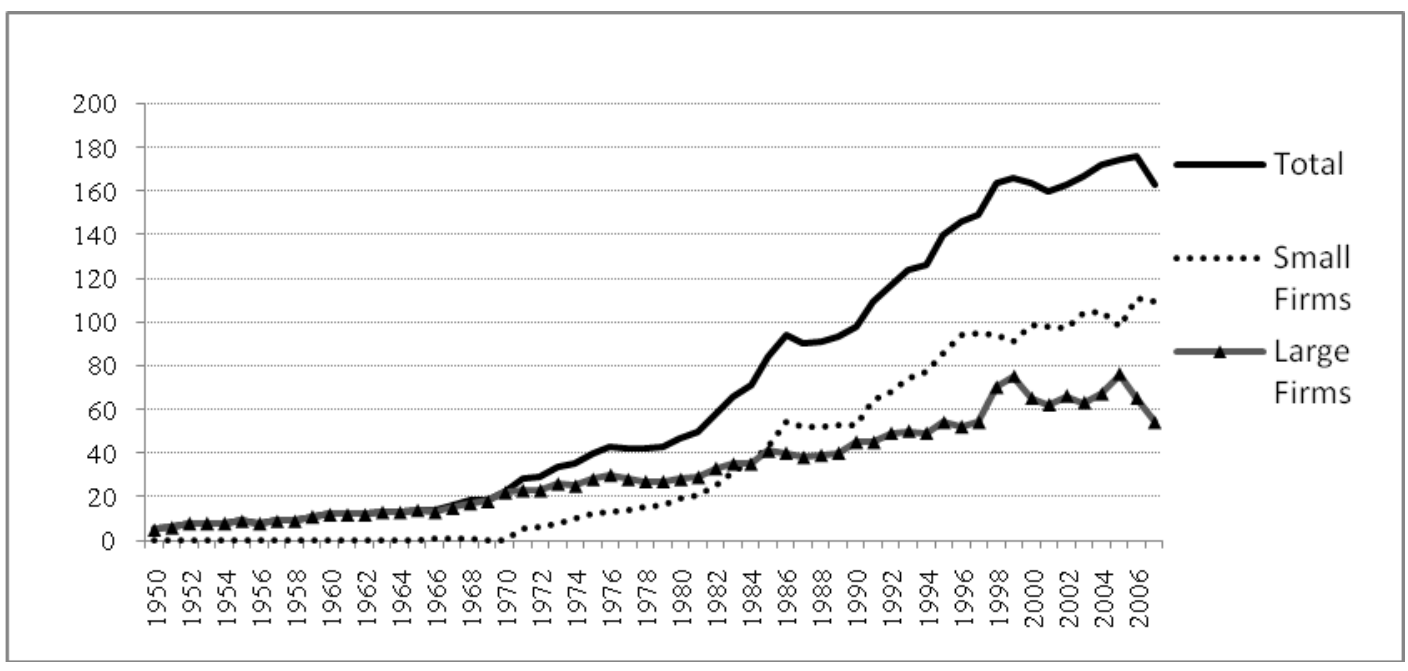

Note: Small firms have less than 500 employees and large firms 500 employees or more. 


\section{Figure 3: Share (\%) of Small and Large Firms among Patentee Firms}

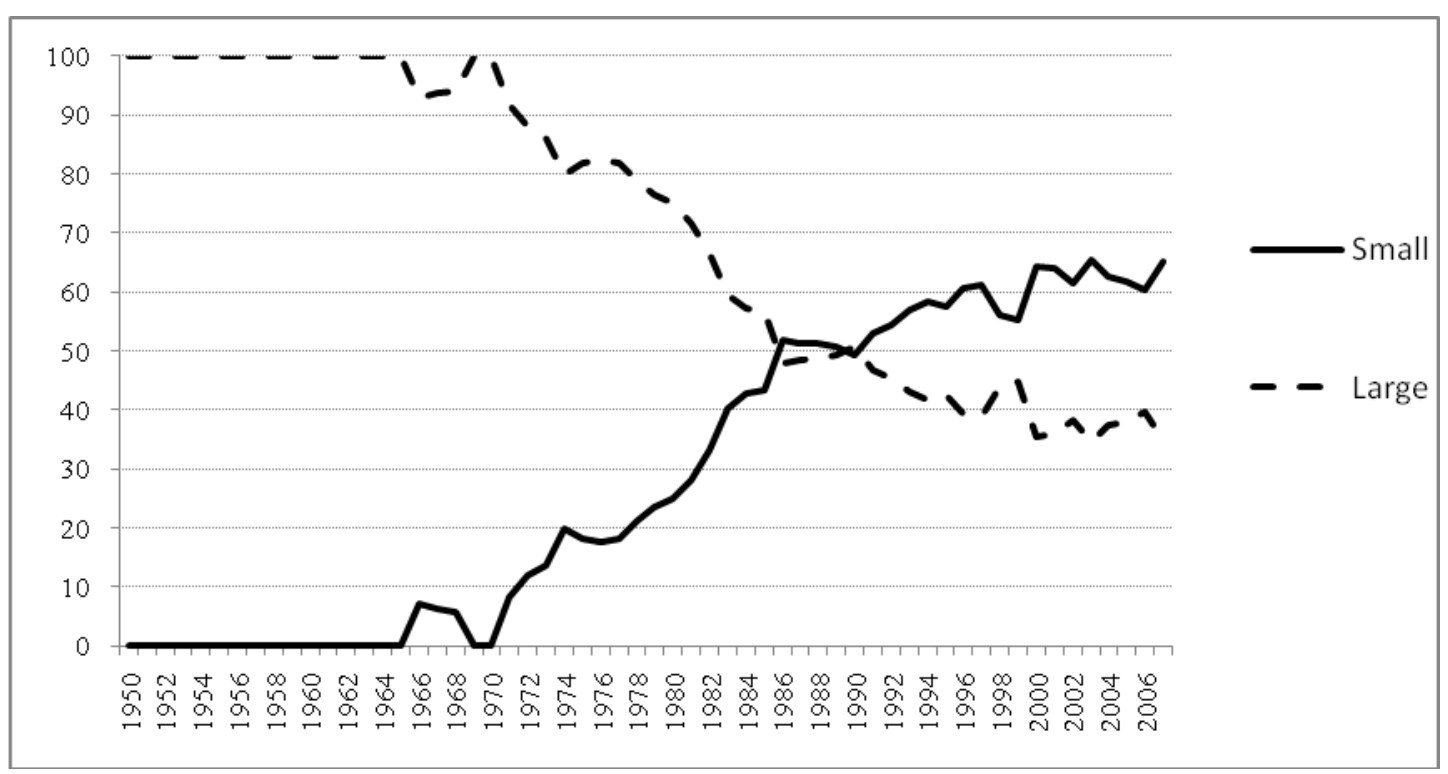

Note: Patentee Firms are those that have been granted at least 1 patent. Small firms have less than 500 employees and large firms 500 employees or more.

\section{(2) Innovative differences within size classes}

Secondly, the innovative activities of firms are not only different across size classes but also within size classes. Among firms of the same size, some firms innovate while many others do not (Nelson and Winter, 1982). Even among the innovators, there exists a wide range of differences in R\&D capabilities, sources of innovation (e.g. suppliers/customers/scientific developments), degrees of innovativeness and innovative persistence (Utterback and Suarez, 1993). The degree of persistence in innovative activities within an industry determines the degree to which innovations build on existing knowledge and capabilities, and consequently, whether the identity of innovators persists over time (i.e. the probability of established innovators being replaced by new ones). Many studies have found that most innovating firms tend to innovate occasionally rather than persistently (Geroski et al.,1997). The few persistent innovators, however, are the source of majority of innovations in each industry (Cefis, 2003).

Figure 4 shows the heterogeneity in the patenting capabilities within the size classes of small and large pharma firms. While there are a large number of firms that do not patent (i.e. non-patentees) in each size category, only a portion of the patentee firms patent persistently (i.e. persistent) for five consecutive years. 
Figure 4: Heterogeneity in Patenting Capabilities of Small and Large Firms

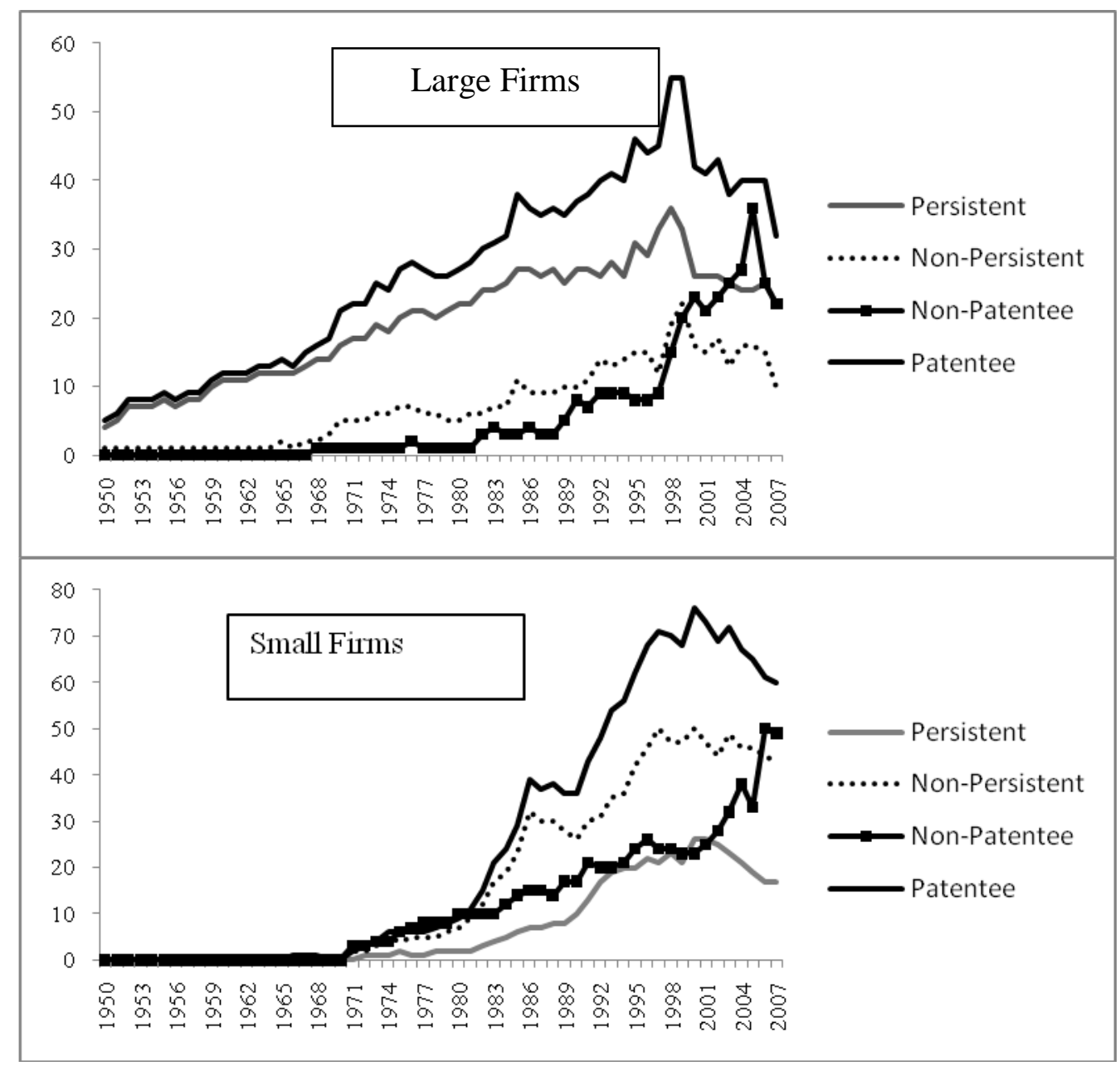

Note: Small firms have less than 500 employees and large firms 500 employees or more. Patentee Firms are those that have been granted at least 1 patent. Persistent patentee firms have a minimum of 5 consecutive years of patenting activity.

We explore if (and when) differences in innovative characteristics of firms affect whether firms' $R \& D$ efforts lead to sales growth in the pharmaceutical industry. We test the relationship between $R \& D$ and firm growth conditional on firm size (i.e. for small and large firms), firm patenting activity (i.e. patentees vs. non-patentees) and whether a firm patents persistently for a minimum of five years (i.e. persistent patentees vs. non-persistent patentees) ${ }^{3}$.

\section{Data and Methodology}

The mixed evidence on how (and whether) innovation affects firm growth suggests that there is still much to learn about the innovation-firm growth relationship to improve our understanding of

\footnotetext{
${ }^{3}$ Note that patenting activity is used as a signal of innovative behaviour where the actual innovation would be a new drug.
} 
the conditions under which market selection rewards innovators-making the spending worth it. We approach the problem by building a simple firm growth model where the growth rate is regressed on the $R \& D$ intensity of the firm while we control for firm size and the number of years a firm has been quoted on the stock exchange. We investigate the impact of innovation on firm growth for small and large publicly quoted firms by testing the differences within each size class between patentee and non-patentee firms as well as those between persistent patentees and nonpersistent patentees.

\subsection{Dataset}

The data on pharma firms comes from merging the COMPUSTAT and NBER patent and citation databases (Hall, 2001 and Hall et al, 2005). We have used the COMPUSTAT database to extract sales, employment and R\&D expenditures for all publicly quoted pharma firms listed under the GICS Code $352020^{4}$ between 1950 and $2008^{5}$. Although this database is limited to publicly quoted firms, and hence excludes the very small firms which might have never been listed on the stock exchange, the fact that all the most innovative players that spend money on R\&D in this industry are in fact very likely to be listed on the stock market regardless of their size, makes this potential selection bias less of an issue for our paper. We used the NBER patent database to extract the number of patents per year for each firm. The patent data is used to classify firms into groups based on their innovative behaviour: patentees vs. non-patentees and persistent patentees vs. nonpersistent patentees. Categories 1 to 4 in Table 1 include full definitions of patent based firm categories used in this study. Since actual innovations in this industry are the new drugs (not patents), we use patents as a 'signal' of a firm's innovative effort, along with its R\&D spending. Categories 5 and 6 are based on employment and reflect firm size.

${ }^{4}$ GICS is an industry classification scheme developed by Standard \& Poor's and MSCI Barra. It consists of 10 sectors, 24 industry groups, 68 industries and 154 sub-industries. The scheme is widely accepted among investment researchers, portfolio and asset managers as one of the most commonly used industry classifications in the world. The "map" or matrix of GICS codes is available at : http://www.standardandpoors.com/indices/gics/en/us.

${ }^{5}$ The R\&D and Sales figures obtained from the COMPUSTAT database are deflated by the US Medical Care Inflation Index to adjust for inflationary effects and are presented in 1982-84 real terms. 
Table 1: Description of Firm Categories

\begin{tabular}{|c|c|}
\hline FIRM CATEGORY & DESCRIPTION \\
\hline 1. Patentees & Firms that own at least one patent. \\
\hline 2. Non-Patentees & Firms that do not own any patents. \\
\hline 3. Persistent Patentees & $\begin{array}{l}\text { Patentee firms that have patented for at least five } \\
\text { consecutive years. }\end{array}$ \\
\hline 4. Non-persistent Patentees & $\begin{array}{l}\text { Patentee firms that have not patented for at least five } \\
\text { consecutive years. }\end{array}$ \\
\hline 5. Small Firms & Firms with less than 500 employees in a given year. \\
\hline 6. Large Firms & Firms with at least 500 employees in a given year. \\
\hline
\end{tabular}

To account for mergers and acquisitions (M\&A) that occurred between 1950 and 2008, we have screened six sources including Who Owns Whom, International Hoover's Company Profiles, International Corporate Affiliations, Directory Information, ABI US Business and US Company Capsules and made a note of all firms that were subject to an M\&A. Using the 'super-firms' methodology we restructured the dataset by assuming that any two (or more) firms that merged between 1950 and 2008 merged from the database's start date and we united their firm level data (see Bottazzi et al., 2001 for details of the 'super-firms' methodology). Similarly, if a firm has spun off from another, the two firms are re-merged starting from the spin-off date. The final database is an unbalanced panel of 248 firms over the period 1950- 2008.

The 'panel' nature of the dataset allows us to (1) control for firm heterogeneity, (2) deal with the causality and 'endogeneity' problems that characterise the innovation-firm growth relationship and (3) gain an understanding of how the innovation firm growth relationship evolved over the years. The endogeneity problems are the same as those found in all studies that look at the relationship between innovation and performance: is it the innovation that increases growth, or growth that increases the funds to spend on innovation? As discussed below, we solve this endogeneity problem using 'instrumental' variables. 


\subsection{Description of Variables}

To measure the growth of firms, we concentrate on an output measure: the annual percentage change in sales. Sales, $S_{i, t}$, are measured in logarithms $\left(\log S_{i, t}\right)$ for firm i in year $\mathrm{t}$. The growth rate, $\left(g r_{i, t}\right)$, for firm $\mathrm{i}$ in year $\mathrm{t}$ is the change in firm sales

from year t-1 to year t (i.e. $g r_{i, t}=\log S_{i, t}-\log S_{i, t-1}$ ).

$\mathrm{R} \& \mathrm{D}$ intensity $\left(\operatorname{RDin}_{i, t}\right)$ is defined as the $\mathrm{R} \& \mathrm{D}$ for firm $\mathrm{i}$ in year $\mathrm{t}$ as a share of its sales in year $\mathrm{t}-1$ $\left(\operatorname{RDin}_{i, t}=\frac{R \& D_{i, t}}{S_{i, t-1}}\right)$. We divide the R\&D variable with the lagged value of sales instead of the current year's sales to avoid potential problems that arise due to correlation between the right hand side sales variable $\log S_{i, t}$ and the denominator of the $R D i n_{i, t}$ variable (Hall and Mairesse, 1995).

Finally, we have constructed a 'public age' variable ( $\left.P u b A g e_{i, t}\right)$ that reflects the number of years the firm has been quoted on the stock exchange. This is a proxy for the firm's experience as a 'publicly held' firm and is helpful in capturing the age differences between new and established firms as well as adjusting for the fact that IPOs have become easier for the small science based firms with innovative potential after 1980s.

The main descriptive statistics for Net Sales, Employment, R\&D expenditures and Public Age are presented in Table 2.

Table 2: Descriptive Statistics

\begin{tabular}{|l|l|l|l|l|}
\hline Variable & Min & Max & Mean & St.Dev \\
\hline Net Sales (\$Mil) & 0 & 294.37 & 11.88 & 32.18 \\
\hline Net Sales (Patentees) (\$Mil) & 0 & 294.37 & 15.28 & 36.04 \\
\hline Net Sales (Non-Patentees) (\$Mil) & 0 & 205.70 & 2.00 & 11.72 \\
\hline Net Sales (Persistent Patentees) (\$Mil) & 0 & 294.37 & 27.74 & 46.28 \\
\hline Net Sales (Non-Persistent Patentees) (\$Mil) & 0 & 61.20 & 1.78 & 6.09 \\
\hline Net Sales (Small Firms) (\$Mil) & 0 & 3.24 & .13 & .24 \\
\hline Net Sales (Large Firms) & 0 & 294.37 & 24.92 & 43.14 \\
\hline Number of Employees (thousands) & .001 & 165.67 & 9.94 & 21.18 \\
\hline Number of Employees (Patentees) (thousands) & .001 & 165.67 & 12.56 & 23.34 \\
\hline Number of Employees (Non- Patentees) (thousands) & .001 & 100.29 & 1.72 & 7.75 \\
\hline
\end{tabular}




\begin{tabular}{|l|l|l|l|l|}
\hline Number of Employees (Persistent Patentees) (thousands) & .003 & 165.67 & 22.39 & 28.46 \\
\hline Number of Employees (Non-Persistent Patentees) (thousands) & .001 & 55 & 1.78 & 5.58 \\
\hline R\&D Expenditures (\$Mil) & 0 & 66.21 & 1.31 & 4.20 \\
\hline R\&D Expenditures (Patentees) (\$Mil) & 0 & 66.21 & 1.64 & 4.61 \\
\hline R\&D Expenditures (Non-Patentees) (\$Mil) & 0 & 53.43 & 0.34 & 2.41 \\
\hline R\&D Expenditures (Persistent-Patentees) (\$Mil) & 0 & 66.21 & 2.95 & 6.01 \\
\hline R\&D Expenditures (Non-Persistent-Patentees) (\$Mil) & 0 & 32.2173 & .2280039 & 1.169313 \\
\hline R\&D Expenditures (Small Firms) (\$Mil) & 0 & 1.15 & .051 & .08 \\
\hline R\&D Expenditures (Large Firms) (\$Mil) & & & & \\
\hline Public Age & 2 & 58 & 11.03 & 10.60 \\
\hline
\end{tabular}

Note: Net Sales and Research and Development Expenditures have been deflated and are presented in 1982-1984 real terms.

\subsection{Methodology}

We study the innovation-firm growth relationship by looking at the effect of $R \& D$, on the rate of firm growth. We control for the size of a firm's sales and its age (public age) as is commonly done in firm growth studies (Dunne and Hughes, 1994; Yasuda, 2005).

We use Equation 1 to explore the impact of innovation on firm growth. As explained in Section 3.2, the (lagged) firm sales, Public Age of firms and the (lagged) R\&D intensity are regressed upon the growth rate of firm $i$ at time $t$.

$$
g r_{i, t}=\beta_{0}+\beta_{1} \log \left(S_{i, t-1}\right)+\beta_{2} R \operatorname{Din}_{i, t-1}+\beta_{3} \log \left(P u b A g e_{i, t}\right)+\varepsilon_{i, t}
$$

Besides observed firm characteristics such as sales, age and $R \& D$ intensity, the use of panel data allows us to account for the impact of unobserved heterogeneity among the firms using the fixed effects (FE) or random effects (RE) technique. The Hausman specification tests reveal that the fixed effects specification is a better fit for our data in all of the equations and samples we work with. This specification allows for the unobserved firm specific effects to be correlated with the independent variables. Alongside with the fixed firm effects, we also introduce fixed time effects to control for the years in our equations.

We recognize that a firm's R\&D investment is an endogenous strategy that is implemented on the basis of the costs and potential outcomes of R\&D as well as the institutional, legal and economic settings that determine the success and profitability of these outcomes (Grossman and Helpman, 
1994). To accommodate the endogenous nature of $R \& D$ investments, we use the two-stage-leastsquares estimator with fixed effects (i.e. within estimator) where the variable is modeled as an endogenous variable such that the pre-determined values of $R \& D$ intensity can constitute valid instruments for this variable.

Equation 1 is estimated for the whole sample as well as the subsamples based on categories described in Table 1 including the combinations across innovation and firm size categories (such as small persistent patentees). We also look at the effect of $R \& D$ on growth in two different time periods, the period before 1985, and the period after 1985. Looking at these two periods allows us to ask whether the change in 'innovation regime', affects the innovation-growth relationship.

\section{Analysis and Results}

The regression results based on Equation 1 are reported in Tables A1, A2 and A3 in Appendix 1 where coefficient estimates for different samples are displayed.

\subsection{Control Variables: Sales and Public Age}

The lagged sales variable has a significant and negative impact on firm growth across all firm categories in both the pre and post 1985 periods. This suggests that smaller firms (as measured by sales, not employment) have a tendency to grow faster, a result commonly found in firm growth studies (Evans, 1987; Sutton, 1999).

The 'public age' variable appears to have a positive impact on firm growth but this impact is only significant during the post-1985 period. We note that the positive sign of this variable is unexpected as previous studies report that the impact of age on growth is often negative suggesting that growth slows down as firms age (Dunne and Hughes, 1994; Evans, 1987).

A potential explanation to why the impact of public age is positive in our findings may relate to the positive associations of being "publicly-held" for a longer period of time. Firms that start to float on the stock market are subject to relaxed financial constraints, financial constraints being a well known factor that limits firm growth (Carpenter and Petersen, 2002). The finding that the 'public age' variable is only significant in the post 1985 period further supports this view because this time period is dominated by the IPOs of small pharmaceutical firms which benefited from relaxed financial constraints.

\subsection{R\&D Intensity}

Unlike the control variables size and public age, the impact of $R \& D$ intensity on firm growth appears to be conditional on sample characteristics. When the whole sample for the 
pharmaceutical industry is considered, we find that $R \& D$ intensity affects growth positively, potentially good news for the Lisbon Agenda. However, a closer look into this relationship by dividing the sample into subsamples based on (1) patenting behaviour (2) time period and (3) firm size shows that only certain types of firms experience a sales growth that results from R\&D. We have instrumented the lagged $\mathrm{R} \& \mathrm{D}$ intensity variable $R \operatorname{Din}_{i, t-1}$ with a further lag $R \operatorname{Din}_{i, t-2}$. The Sargan statistics confirm the validity of this instrument. Below we summarize the impact of R\&D on firm growth for the different samples we work with.

\subsubsection{Differences in Patenting Behaviour: 1950-2008}

Table 3 (based on results in Table A1) summarizes the impact of R\&D intensity on firm growth between 1950 and 2008 for the whole sample as well as for several subsamples of firms with different patenting characteristics. For the whole of the pharma industry, R\&D appears to affect growth positively. Yet, the impact of R\&D intensity on growth differs for firms with different patenting behaviour. In particular, we find that $R \& D$ is a driver of firm growth only for persistent patentees. Those firms that do not patent (i.e. non-patentees) or patent sporadically (i.e. nonpersistent patentees) do not grow in response to their $R \& D$ investments.

Table 3: Impact of R\&D on Sales Growth for Firms with Different Innovative Characteristics (1950-2008)

\begin{tabular}{|l|c|l|}
\hline SAMPLE & Impact on sales growth & Significant? \\
\hline Whole Sample & + & YES \\
\hline Patentees & + & YES \\
\hline Non-Patentees & + & NO \\
\hline Persistent Patentees & + & YES \\
\hline Non-persistent Patentees & - & NO \\
\hline
\end{tabular}

Note: Summary based on Table A1.

Persistence in innovative activities, in particular patenting, has been widely discussed in the literature with the main emphasis centred on the existence and nature of innovative persistence and the reasons behind it (Cefis, 2003; Geroski et al. 1997; Peters, 2009). Our findings contribute to this literature by highlighting the role of innovative persistence for firm performance. We find that $R \& D$ in absence of persistence in patenting, fails to transfer into firm growth. This has major implications for our understanding of how markets reward innovators: innovative persistence appears a key criterion of market selection through which innovation is rewarded with growth. 
In the next step, we divide the sample further to compare the relationship between R\&D intensity and growth in the pre-1985 (See Table 4 based on Results in Table A2) and post-1985 (See Table 5 based on Results in Table A2) periods. The differences in how R\&D affects growth during different time periods of the industry history is interesting in the light of how innovation dynamics evolved in this industry. The drug discovery techniques changed significantly starting from early 1970s due to major developments in biology, genetic engineering, enzymology and bioinformatics, (Henderson et al., 1999). With these scientific advances, pharmaceutical scientists were able to identify the mechanism by which the active compound of a drug binds to targets associated with diseases. This development opened up more structured avenues of research where one could design illustrations of 'ideal' molecules that would cure a certain disease. The ability to design ideal molecules allowed scientific research to follow a more cumulative and systematic path. As 'Drug discovery by design' gradually replaced the 'random screening' processes which relied more on trial and error (Gambardella, 1995) and became the accepted and common research technique used in the industry by the 1980s (Malerba and Orsenigo, 2002), it became possible to build on the existing knowledge base of the causes of human disorders and the action mechanisms of drugs. This eventually led to a more path-dependent and cumulative innovation regime.

The results for the pre-1985 period suggest that R\&D was not a significant driver of growth for any of the firm categories listed in Table 1 . It is only in the post-1985 period that we find R\&D to affect firm growth significantly and this result, once again, only applies to persistent patentees ${ }^{6}$.

Table 4: Impact of R\&D on Sales Growth for Firms with Different Innovative Characteristics (1950-1984)

\begin{tabular}{|l|c|l|}
\hline SAMPLE & Impact on sales growth & Significant? \\
\hline Whole Sample & - & NO \\
\hline Patentees & - & NO \\
\hline Non-Patentees & + & NO \\
\hline Persistent Patentees & - & NO \\
\hline Non-persistent Patentees & - & NO \\
\hline
\end{tabular}

Note: Summary based on Table A2.

${ }^{6}$ To check whether results are sensitive to the cut-off date of 1985 , we have experimented with different cut off dates such as 1983, 1984 and 1986. The results are robust to the choice of these dates. 
Table 5: Impact of R\&D on Sales Growth for Firms with Different Innovative Characteristics (1985-2008)

\begin{tabular}{|l|c|l|}
\hline SAMPLE & Impact on sales growth & Significant? \\
\hline Whole Sample & + & YES \\
\hline Patentees & + & YES \\
\hline Non-Patentees & + & NO \\
\hline Persistent Patentees & + & YES \\
\hline Non-persistent Patentees & - & NO \\
\hline
\end{tabular}

Note: Summary based on Table A2.

Our results suggest that R\&D only became a significant determinant of firm growth in the post 1985 period when R\&D efforts were more guided and systemised. This result is in fact intuitive, given that scale economies, leading to persistence, are more likely to occur in a period in which the search process is guided, allowing large firms to reap advantages from their previous search. Instead, in the earlier period, the 'trial and error' component of R\&D may have prevented large firms from gaining persistent advantages - success today is not an indicator of success tomorrow when innovation is 'random'.

\subsubsection{Differences in Size}

In the final step, we look at the effect of firm size (Small vs. Large firms) on the relationship between $R \& D$ and growth. We have classified firms as small if they have less than 500 employees in a given year and large if they have at least 500 employees in a given year. ${ }^{7}$ Table 6 (based on Table A3) displays a summary of the results. The results suggest that large firms' $R \& D$ efforts generally result in increased sales growth. The only exception in which $R \& D$ fails to generate sales growth is the case of large non-patentee firms. It is interesting to note that those large firms that do not patent persistently are still able to boost their sales through $R \& D$ expenditures.

On the contrary, for small firms, R\&D does not appear to be as a strong driver of sales growth. Even small patentee firms fail to achieve increased sales growth by means of R\&D unless they patent persistently for a minimum of five consecutive years. Hence, persistence in innovation seems to be the key to innovation led growth for small firms.

\footnotetext{
${ }^{7}$ Note that we do not further divide this sample as pre and post 1985 as there are only few small firms in the pre-1985 period and the comparison between small and large firms would not be effective.
} 
Table 6: Impact of R\&D on Sales Growth for Small and Large Firms with Different Innovative Characteristics (1950-2008)

\begin{tabular}{|l|l|l|l|l|l|}
\hline & Patentees & $\begin{array}{l}\text { Non- } \\
\text { Patentees }\end{array}$ & $\begin{array}{l}\text { Persistent } \\
\text { Patentees }\end{array}$ & Non-Persistent & Full Sample \\
\hline Small & Insignificant & Insignificant & Significant & Insignificant & Insignificant \\
& + & + & + & - & + \\
\hline Large & Significant & Insignificant & Significant & Significant & Significant \\
& + & + & + & + & + \\
\hline
\end{tabular}

Note: Summary based on Table A3.

\section{Implications for the 'structure' underlying 'fat tailed' growth distributions}

Recent studies have revealed that firm growth rate distributions (FGD) do not follow a 'normal' Gaussian distribution, as is often assumed in microeconomic theory. Across different sectors, FGD appear to have tent-like, fat tailed shapes that exponential (Laplace) distributions (or an even fatter tailed distributions like the Subbotin family of distributions, as discussed in Bottazzi and Secchi, 2005). The FGD for the pharmaceutical industry is no exception.

Different studies interpret fat tails as evidence of dynamic increasing returns to scale, such as economies of scale and scope, network externalities and increasing returns to knowledge accumulation (Bottazzi and Secchi 2005; Jensen, 2005, Coad and Rao, 2008). Dosi (2005) argues that fat tails imply much richer structure in the growth dynamics than that assumed by Gibrat's law - due possibly to the correlation between growth rates (one firm's gain is another's loss) as well as to the Schumpetarian wave-like behavior of technology shocks . However, none of these studies empirically explore how innovation affects the "structure" underlying fat tails in the FGD. This is where we turn to next.

In this final section of the paper, we complement our analysis of firm growth and innovation by looking at the shape of the FGD for subsamples of our data for which we have explored the relationship between R\&D and firm growth in Section 4. Table 7 below shows the kurtosis values for different time periods and firm categories. The kurtosis value of a distribution indicates the degree to which it has fat tails. The Gaussian distribution has a kurtosis value of 3 and distributions with kurtosis values higher than 3 are known to have fatter tails compared to that of a Gaussian distribution. While the kurtosis figures are not very sophisticated measures of 
'fatness' in the tails of FGD, our purpose here is to simply give the reader an idea about the structure of firm growth distributions in this industry and how they might reflect the characteristics that we found important in the sections above: firms of different size and different patenting behavior.

Important findings from Table 7 include:

a) The FGD has fat tails for all firm categories, yet the degree of "fatness" is different for different types of firms.

b) The FGD of large firms display fatter tails compared to the FGD of smaller firms.

c) The FGD for persistent patentees displays fatter tails than that of the non-persistent patentees.

Table 7: Kurtosis Values for Firm Growth Rate Distributions for Different Firm Types and Different Periods of the Industry

\begin{tabular}{|c|c|c|}
\hline Sample Description & Number of Observation Points & Kurtosis Value \\
\hline Whole Sample & 3295 & 16.38 \\
\hline Pre-1985 period & 788 & 23.39 \\
\hline Post-1985 Period & 2507 & 13.34 \\
\hline Patentee Firms & 2534 & 14.14 \\
\hline Non-Patentee Firms & 761 & 20.31 \\
\hline Persistent Patentees & 1405 & 23.23 \\
\hline Non-Persistent Patentees & 1890 & 13.26 \\
\hline Small Firms & 1651 & 8.47 \\
\hline Large Firms & 1644 & 68.44 \\
\hline Small Patentees & 1137 & 7.73 \\
\hline Small Non-Patentees & 514 & 10.68 \\
\hline Small Persistent Patentees & 356 & 8.84 \\
\hline Small Non-Persistent Patentees & 1295 & 8.35 \\
\hline Large Patentees & 1397 & 43.88 \\
\hline Large Non-Patentees & 247 & 38.43 \\
\hline Large Persistent Patentees & 1049 & 53.46 \\
\hline Large Non-Persistent Patentees & 595 & 52.71 \\
\hline
\end{tabular}


Thus, in the pharma industry, the 'fat tailed' distribution, which has puzzled industrial economists in recent years, largely emerges due to the presence of large firms and those firms that patent persistently. These two characteristics are exactly those characteristics that we found to play a critical role in the R\&D-growth relationship.

\section{Conclusions}

Understanding the firm specific characteristics and activities that determine which firms are most likely to grow is essential for designing effective growth policies. The paper was motivated by the fact that, although there are many policies at the national and transnational level, that call for firms to invest more in $R \& D$, there is a scarcity of empirical studies which provide evidence on whether this will have any effect on their growth. Hence, not clear on whether it is worth the money.

The paper studies the role R\&D plays in driving firm growth in the US pharmaceutical industry between 1950 and 2008 during which the size composition of firms and the characteristics of innovation evolved significantly.

Our findings suggest that the fitness criteria upon which market selection processes operate is a mix between firm size and the different aspects of the firms' innovative activities. Results show that the impact of innovation on firm growth is far from being a simple relationship. We find that for large firms, patenting is the main criterion that allows firms to grow through their R\&D efforts. For small firms, on the other hand, it seems harder to achieve R\&D led growth: Patenting, per se, does not seem to suffice in driving firm growth through $R \& D$. It is crucial that small firms patent persistently for at least five years in a row for R\&D efforts to result in firm growth.

The different impact of innovation for the growth of small and large firms has important implications for government policies that are aimed at an innovation led economic growth. The EC's Lisbon Agenda (2005) which has set an R\&D target of 3\% of GDP has been the overarching theme in EU countries' innovation policies. But to achieve growth from this spending we need a more detailed and sophisticated understanding of the conditions under which R\&D is most likely to lead to economic growth - and how such conditions differ between industries (e.g. high-tech, medium tech, low tech, manufacturing, services etc.), between periods in the industry life-cycle, and between different types of firms (e.g. young, public, high advertisers, etc). Studies, such as ours, providing evidence of what types of combinations are necessary for R\&D to affect growth, and how these combinations differ between sectors, will allow policy makers to better target innovation-led growth policies. 
Finally, the paper makes an initial inquiry into the factors that lead to the emergence of fat tails in growth rate distributions. Our results suggest that the degree of fat tails is related to the dynamics of innovation-something that was suggested by previous studies, but not tested. The growth rates of large firms and of persistent patentees exhibit fatter tails than the rest of the firms in our sample - exactly those firms which we found to grow more as a result of their R\&D spending. The determinants of such tails will no doubt differ between sectors. For example, our work in progress has found that the tails of the FGD in industries which rely on a division of 'innovative' labor between large and small firms is affected by 'alliances'. And since the assumption of a normal distribution often underlies theories and econometric tests justifying different policies, it is fundamental that the structure underlying such distributions be better understood so that the models informing them are not misinformed. 


\section{References}

Almus, M., and E. A. Nerlinger. 1999. Growth of New Technology-Based Firms: Which Factors Matter? Small Business Economics 13 (2):141-154.

Bottazzi, G., G. Dosi, M. Lippi, F. Pammolli, and M. Riccaboni. 2001. Innovation and corporate growth in the evolution of the drug industry. International Journal of Industrial Organization 19 (7):1161-1187.

Brouwer, E., Kleinknecht, A.,, and J. O. N. Reijnen. 1993. Employment Growth and Innovation at the Firm Level. Evolutionary Economics 3 (153-159).

Carpenter, R. E., and B. C. Petersen. 2002. Capital Market Imperfections, High-Tech Investment, and New Equity Financing. The Economic Journal 112 (477):54-72.

Cefis, E. 2003. Is there persistence in innovative activities? International Journal of Industrial Organization 21 (4):489-515.

Coad, A., and R. Rao. 2008. Innovation and firm growth in high-tech sectors: A quantile regression approach. Research Policy 37 (4):633-648.

Del Monte, A., and E. Papagni. 2003. R\&D and the growth of firms: empirical analysis of a panel of Italian firms. Research Policy 32 (6):1003-1014.

Dunne, P., and A. Hughes. 1994. Age, Size, Growth and Survival: UK Companies in the 1980s. The Journal of Industrial Economics 42 (2):115-140.

Evans, D. S. 1987. Tests of Alternative Theories of Firm Growth. The Journal of Political Economy 95 (4):657-674.

Freel, M. S., Robson, Paul J. A. 2004. Small Firm Innovation, Growth and Performance: Evidence from Scotland and Northern England. International Small Business Journal 22:561-575.

Gambardella, A. 1995. Science and Innovation in the US Pharmaceutical Industry. Cambridge: Cambridge University Press.

Geroski, P., and S. Machin. 1992. Do Innovating Firms Outperform Non-Innovators?. Business Strategy Review 3 (2):79-90.

Geroski, P. A., and S. Toker. 1996. The turnover of market leaders in UK manufacturing industry, 1979-86. International Journal of Industrial Organization 14 (2):141-158.

Geroski, P. A., J. Van Reenen, and C. F. Walters. 1997. How persistently do firms innovate? Research Policy 26 (1):33-48.

Gibrat, R. 1931. Les Inegalites Economiques. Paris: Librairie du Recueil Sirey.

Grossman, G. M., and E. Helpman. 1994. Endogenous Innovation in the Theory of Growth The Journal of Economic Perspectives 8 (1):23-44.

Hall, B. H., and J. Mairesse. 1995. Exploring the Relationship Between R\&D and Productivity in French Manufacturing Firms. Journal of Econometrics 65:263-293. 
Henderson, R., L. Orsenigo, and G. Pisano. 1999. The Pharmaceutical Industry and the Revolution in Molecular Biology: Interactions Among Scientific, Institutional and Organizational Change. In Sources of Industrial Leadership, edited by D. M. R. Nelson. Cambridge: Cambridge University Press.

Hopkins, M. M., P. A. Martin, P. Nightingale, A. Kraft, and S. Mahdia. 2007. The Myth of the Biotech Revolution: An Assessment of Technological, Clinical and Organisational Change. Research Policy 36:566-589.

Klepper, S. (1996). Entry, Exit, Growth, and Innovation over the Product Life Cycle. The American Economic Review, 86(3), 562-583.

Lööf, H., and A. Heshmati. 2006. On the Relationship between Innovation and Performance:A Sensitivity Analysis. Economics of Innovation and New Technology 15 (4/5):317-344.

Mason, G., K. Bishop, and C. Robinson. 2009. Business Growth and Innovation: The wider impact of rapidly-growing firms in UK city-regions, edited by NESTA. London.

McKinnon, R., Worzel, K., Rotz, G., \& Williams, H. 2004. Crisis? What Crisis? A Fresh Diagnosis of Big Pharma's R\&D Productivity Crunch: Marakon Associates.

Nelson, R. R., and S. G. Winter. 1982. An Evolutionary Theory of Economic Change: Bellknap Cambridge Mass.

Peters, B. 2009. Persistence of innovation: stylised facts and panel data evidence. The Journal of Technology Transfer 34 (2):226-243.

Santarelli, E., and A. Sterlacchini. 1990. Innovation, formal vs. informal R\&D, and firm size: Some evidence from Italian manufacturing firms. Small Business Economics 2 (3):223228.

Stam, E., and K. Wennberg. 2009. The roles of R\&D in new firm growth. Small Business Economics 33 (1):77-89.

Sutton, J. 1997. Gibrat's Legacy. Journal of Economic Literature, 35: 40-59.

Utterback, J. M., and F. F. Suárez. 1993. Innovation, competition, and industry structure. Research Policy 22 (1):1-21.

Westhead, P., and S. Birley. 1995. Employment Growth in New Independent Owner-Managed Firms in Great Britain International Small Business Journal 13:11-34.

Yasuda, T. 2005. Firm Growth, Size, Age and Behavior in Japanese Manufacturing. Small Business Economics 24,:1-15. 


\section{APPENDIX 1}

Table A1: Dependent variable $g r_{i, t}=\log \left(S_{i, t}\right)-\log \left(S_{i, t-1}\right)$

\begin{tabular}{|c|c|c|c|c|c|c|c|}
\hline Sample Definition & 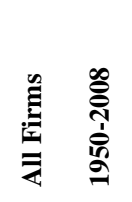 & 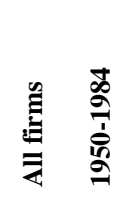 & 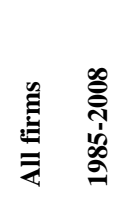 & 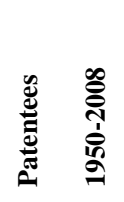 & 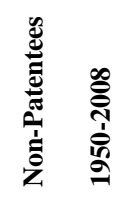 & 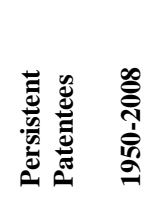 & 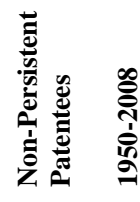 \\
\hline \multirow{2}{*}{$\log \left(S_{i, t-1}\right)$} & $-.306^{* *}$ & $-.102^{* *}$ & $-.367^{* *}$ & $-.30^{* *}$ & $-.29 * *$ & $-.25 * *$ & $-.35 * *$ \\
\hline & $(.016)$ & $(0.017)$ & $(.021)$ & $(.018)$ & $(.048)$ & $(0.022)$ & $(0.035)$ \\
\hline \multirow{2}{*}{$\log \left(R D \operatorname{int}_{i, t-1}\right)$} & .001 & -.049 & .0019 & $.002^{*}$ & .043 & $.003^{* *}$ & -.004 \\
\hline & $(.001)$ & (.159) & $(.002)$ & $(.001)$ & $(0.039)$ & $(0.0008)$ & $(0.013)$ \\
\hline \multirow[t]{2}{*}{$\log \left(\right.$ PubAge $\left._{i, t}\right)$} & $.313^{* * *}$ & .028 & $.42 * *$ & $.314^{* * *}$ & $.282^{* * *}$ & $.249 * *$ & $.378^{* *}$ \\
\hline & $(.028)$ & $(0.019)$ & $(0.048)$ & $(0.031)$ & $(0.096)$ & $(0.032)$ & $(0.062)$ \\
\hline \multirow[t]{2}{*}{ Constant } & $-.745 * *$ & $.125^{* * *}$ & $-1.196^{* *}$ & $-.674 * *$ & $-1.026^{* * *}$ & $-.219 * *$ & $-1.396^{* * *}$ \\
\hline & $(.072)$ & $(0.035)$ & $(.126)$ & $(0.762)$ & $(0.26)$ & $(0.064)$ & (.183) \\
\hline Number of Firms & 248 & 50 & 243 & 173 & 75 & 79 & 94 \\
\hline Number of Observations & 2675 & 660 & 2015 & 2117 & 558 & 1231 & 886 \\
\hline Wald Chi2 & $575.28 * *$ & $151.83^{* * *}$ & $506.63 * *$ & $448.17 * *$ & $74.43^{* * *}$ & 304.09 ** & $169.11^{* *}$ \\
\hline$R$ Squared (within) & .17 & .096 & .20 & .18 & .17 & .20 & .15 \\
\hline Time Dummies & YES & YES & YES & YES & YES & YES & YES \\
\hline
\end{tabular}

Note: ** Significant at $1 \%, *$ Significant at $5 \%$ 
Table A2: Dependent variable $g r_{i, t}=\log \left(S_{i, t}\right)-\log \left(S_{i, t-1}\right)$

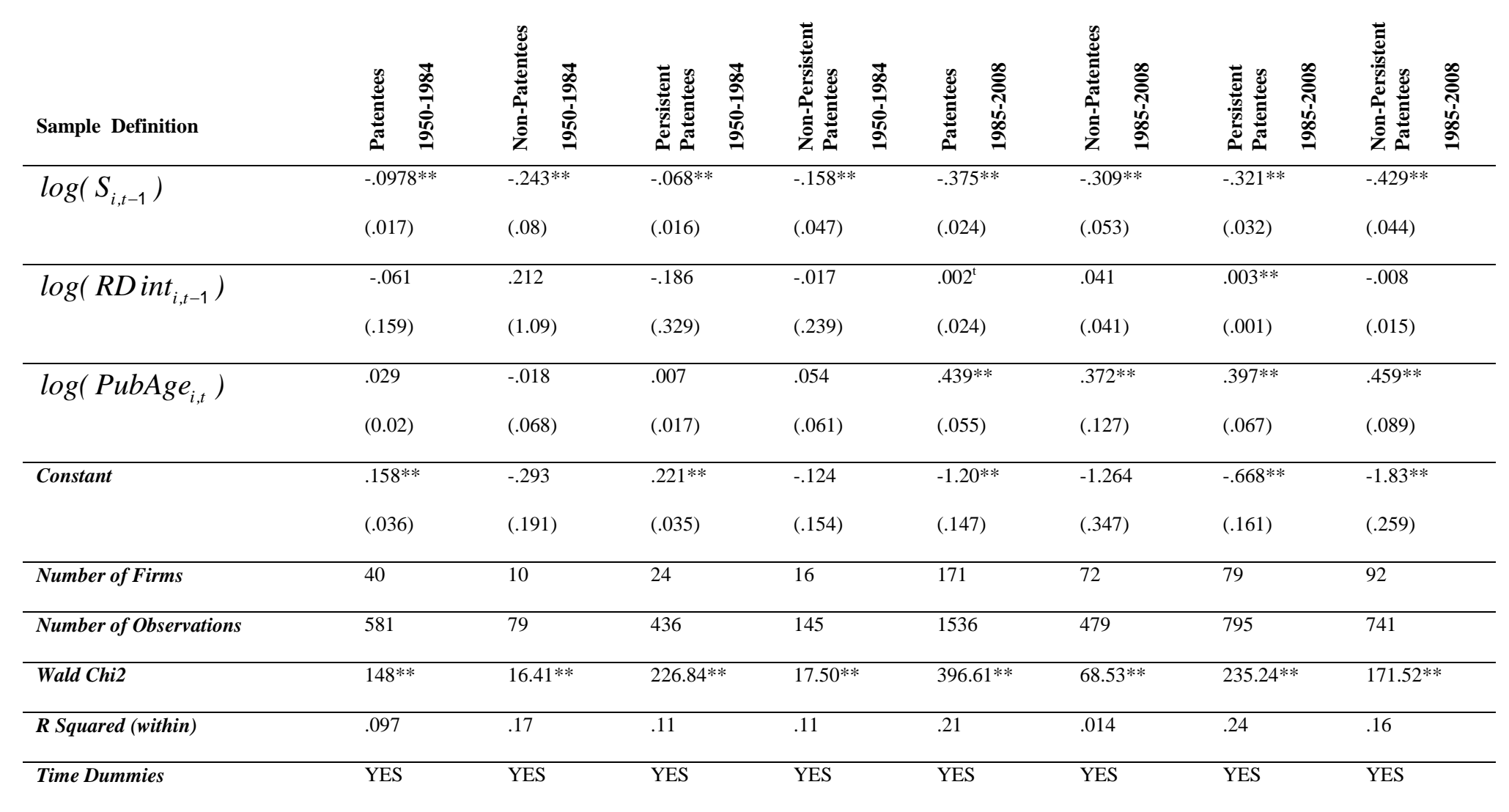

Note: $* *$ Significant at $1 \%, *$ Significant at $5 \%,{ }^{\mathrm{t}}$ Significant at $10 \%$ 
Table A3: Dependent variable $g r_{i, t}=\log \left(S_{i, t}\right)-\log \left(S_{i, t-1}\right)$

\begin{tabular}{|c|c|c|c|c|c|c|c|c|c|c|c|}
\hline Sample Definition & 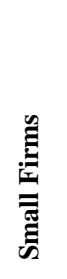 & 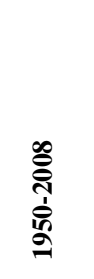 & 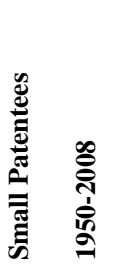 & 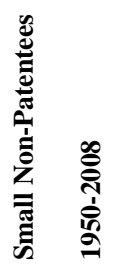 & 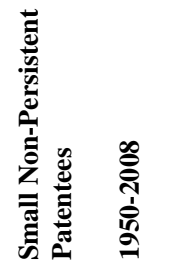 & 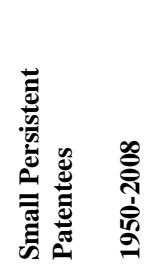 & 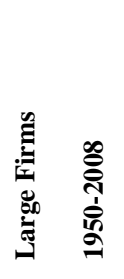 & 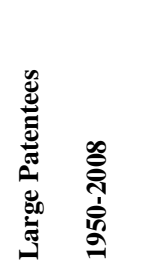 & 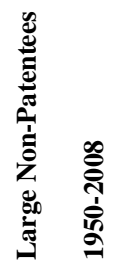 & 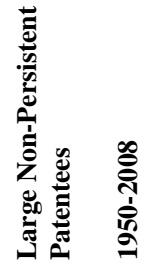 & 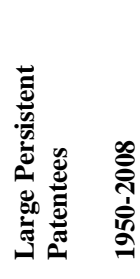 \\
\hline \multirow{2}{*}{$\log \left(S_{i, t-1}\right)$} & & $.387^{* * *}$ & $-.4111^{* *}$ & $-.269^{*}$ & $-.472 * *$ & $-.342 * *$ & $-.242^{* * *}$ & $-.171^{* *}$ & $-.694 * *$ & $-.129^{* *}$ & $-.187 * *$ \\
\hline & & (.029) & $(.037)$ & (.135) & $(.057)$ & $(.065)$ & $(0.024)$ & $(.023)$ & (.117) & (.033) & $(.032)$ \\
\hline \multirow[t]{2}{*}{$\log \left(R D \operatorname{int}_{i, t-1}\right)$} & & .002 & .0024 & .041 & -.013 & $.003^{*}$ & $0.036^{* *}$ & $.102^{*}$ & .016 & .169 ** & $.117^{* *}$ \\
\hline & & $(0.002)$ & $(0.002)$ & $(.086)$ & (.016) & $(.001)$ & $(0.062)$ & $(.050)$ & $(0.011)$ & $(.040)$ & $(.046)$ \\
\hline \multirow[t]{2}{*}{$\log \left(\right.$ PubAge $\left._{i, t}\right)$} & & $349^{* *}$ & $.395^{* * *}$ & $.224 *$ & $.371 * *$ & .429 ** & $.221^{* * *}$ & $.142 * *$ & $.61^{* *}$ & .060 & $.161^{* *}$ \\
\hline & & $(.06)$ & $(0.076)$ & (.106) & $(.096)$ & (.132) & $(0.034)$ & $(.031)$ & (.176) & (.063) & $(.041)$ \\
\hline \multirow[t]{2}{*}{ Constant } & & $1.804 * *$ & $-2.06^{* *}$ & $-1.11^{* *}$ & $-2.171^{* *}$ & $-1.85 * *$ & $-.032 * *$ & $.048 * *$ & $-1.087 * *$ & .038 & .085 \\
\hline & & (.181) & $(0.233)$ & (.387) & $(.295)$ & $(.397)$ & $(0.062)$ & $(.058)$ & $(.385)$ & (.141) & $(.069)$ \\
\hline Number of Firms & & 182 & 121 & 61 & 79 & 42 & 121 & 86 & 35 & 36 & 50 \\
\hline Number of Observations & & 1217 & 851 & 366 & 580 & 271 & 1458 & 1266 & 192 & 306 & 960 \\
\hline Wald Chi2 & & $98.54 * *$ & $216.10^{* *}$ & $88.33^{* * *}$ & $121.89^{* *}$ & $99.03 * *$ & $202.54 * *$ & $150.16^{* * *}$ & $62.77^{* * *}$ & $117.16^{* *}$ & $70.64^{* *}$ \\
\hline R Squared (within) & & .22 & .22 & .20 & .144 & .30 & .21 & .25 & .044 & .19 & .38 \\
\hline $\begin{array}{l}\text { Time Dummies } \\
\mathrm{N}\end{array}$ & YES & & YES & YES & YES & YES & YES & YES & YES & YES & YES \\
\hline
\end{tabular}

